\begin{tabular}{|c|c|c|c|c|c|c|}
\hline \multirow{4}{*}{ Impact Factor: } & ISRA (India) & $=3.117$ & SIS (USA) & $=0.912$ & ICV (Poland) & $=6.630$ \\
\hline & ISI (Dubai, UAE & $=0.829$ & РИНЦ (Russia & $=0.156$ & PIF (India) & $=1.940$ \\
\hline & GIF (Australia) & $=0.564$ & ESJI (KZ) & $=8.716$ & IBI (India) & $=4.260$ \\
\hline & JIF & $=1.500$ & SJIF (Morocco & $=5.667$ & OAJI (USA) & $=0.350$ \\
\hline
\end{tabular}

\section{SOI: $1.1 /$ TAS $\quad$ DOI: $10.15863 /$ TAS \\ International Scientific Journal Theoretical \& Applied Science}

p-ISSN: 2308-4944 (print) e-ISSN: 2409-0085 (online)

Year: 2019 Issue: 08 Volume: 76
QR - Issue

QR - Article

Published: $30.08 .2019 \quad$ http://T-Science.org
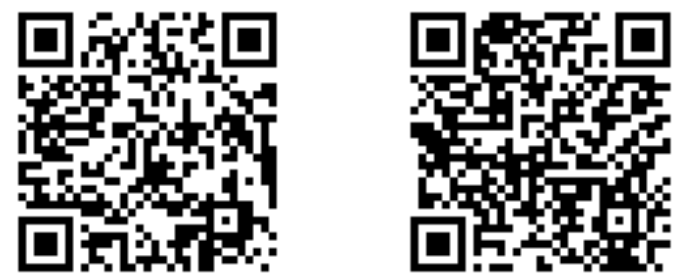

Denis Chemezov

Vladimir Industrial College, M.Sc.Eng., Corresponding Member of International Academy of Theoretical and Applied Sciences, Lecturer, Russian Federation https://orcid.org/0000-0002-2747-552X

chemezov-da@yandex.ru

Aleksandr Petrenko

Vladimir Industrial College, Master of Industrial Training, Russian Federation

Andrey Komissarov

Vladimir Industrial College, Master of Industrial Training, Russian Federation

Oleg Gorbatenko

Vladimir Industrial College,

Master of Industrial Training, Russian Federation

\title{
OPTIMIZATION OF CUTTING MODES WHEN SEMIFINISH AND ROUGH MILLING
}

Abstract: Results of a multifactor experiment that determine the most optimal milling modes of an aluminium billet are presented in the article. Accuracy of machined surfaces of the aluminium billet was determined by calculated values of roughness. Two-dimensional roughness profiles of the machined flat surfaces at a base length were obtained.

Key words: a surface roughness, an end mill, cutting modes, a billet, a base length.

Language: English

Citation: Chemezov, D., Petrenko, A., Komissarov, A., \& Gorbatenko, O. (2019). Optimization of cutting modes when semifinish and rough milling. ISJ Theoretical \& Applied Science, 08 (76), 209-213.

Soi: http://s-o-i.org/1.1/TAS-08-76-27 Doi: croskef https://dx.doi.org/10.15863/TAS.2019.08.76.27

Classifiers: Mechanics and machine construction.

\section{Introduction}

A value of roughness is one of an assessment criterion of the quality of a machined surface of billets. Decreasing of the roughness value of the machined surface of the metal billet is provided by decreasing of a feed and increasing of a rotational speed of the billet (a cutting tool), high rigidity of the technological equipment and other factors. However, compliance with these requirements leads to decreasing of processing performance and increasing of manufacturing cost of a part.

End milling is used to obtaining on the surfaces of the machined billet of open and closed grooves, complex contours and other elements. A milling process is intermittent, since the tool has several cutting blades of a characteristic geometry. When milling, microwaves are formed on the machined surface of the billet, which are equidistant from each other at the distance equal to the mill feed per a tooth $[1-10]$. High rigidity of the metal billet is necessary when high-speed milling, since at its oscillation occur additional processing errors of the surfaces.

A choice of the optimal milling modes of the billet by performing of a multifactor experiment in production and laboratory conditions will reduce the 


\begin{tabular}{|c|c|c|c|c|c|c|}
\hline \multirow{4}{*}{ Impact Factor: } & ISRA (India) & $=3.117$ & SIS (USA) & $=0.912$ & ICV (Poland) & $=6.630$ \\
\hline & ISI (Dubai, UAI & $=0.829$ & РИНЦ (Russia & $=0.156$ & PIF (India) & $=1.940$ \\
\hline & GIF (Australia) & $=0.564$ & ESJI (KZ) & $=8.716$ & IBI (India) & $=4.260$ \\
\hline & JIF & $=1.500$ & SJIF (Morocce & $=5.667$ & OAJI (USA) & $=0.350$ \\
\hline
\end{tabular}

roughness value of the machined surfaces without decreasing of processing performance.

\section{Materials and methods}

Milling of the open grooves on an aluminium plate was carried out on the milling machine with numerical control "DMC 635V Ecoline". Machining was carried out by the end mills with the diameter of $10 \mathrm{~mm}$, which were made of high-speed steel and cemented carbide. The production experiment consisted of 8 tests. The milling modes were changed in each test in accordance with the planning matrix of the full factorial experiment of the type $2^{3}$. The milling modes were adopted at the lower and upper levels: the cutting depth $t-0.5$ and $3 \mathrm{~mm}$; the rotational speed of the mill $n-2000$ and $10000 \mathrm{rpm}$; the billet feed $s-$ 300 and $1500 \mathrm{~m} / \mathrm{min}$. Mechanical processing of the billet was performed when supply of the cutting fluid "ECOCOOL 68 CF3" under pressure. The quality of the machined surfaces of the aluminium billet was researched and presented graphically on the metallurgical microscope "4XB".

\section{Results and discussion}

The images of the machined surfaces of the billet at 100 times magnification were obtained on the metallurgical microscope. The normals along the base length of the machined surfaces of the billet were drawn by special options of the microscope software.

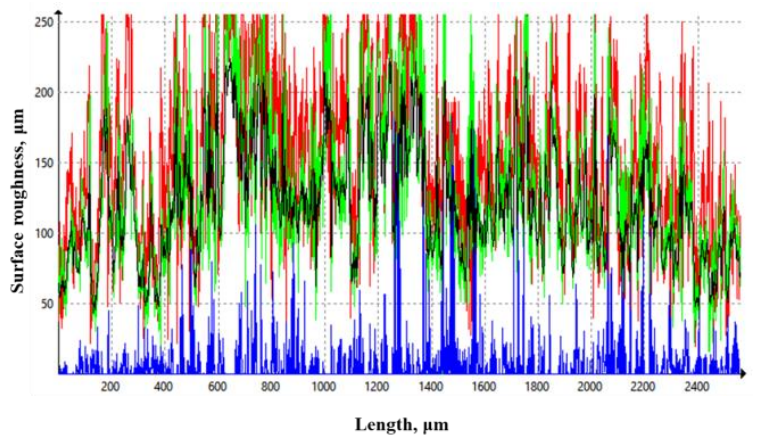

A
The obtained data of the surfaces roughness values were transformed into graphs. The graphic images of roughness of the machined surfaces of the billet after performing of eight tests of the experiment are presented in the Fig. $1-8$.

The base length was $2600 \mu \mathrm{m}$ on which roughness of the machined surface was measured. The maximal measurement range of roughness of the machined surfaces was $0-250 \mu \mathrm{m}$. Let us compare influence of the different values of the cutting modes when milling on the value of roughness of the machined surfaces of the billet. Almost the same value and orientation of the surface roughness were determined when processing by the high-speed and carbide mills on the third $(t=0.5 \mathrm{~mm}, n=10000 \mathrm{rpm}$, $s=300 \mathrm{~m} / \mathrm{min})$ and eighth $(t=3 \mathrm{~mm}, n=10000 \mathrm{rpm}$, $s=1500 \mathrm{~m} / \mathrm{min}$ ) tests of the multifactor experiment. Thus, material of the cutting tool and changing of the cutting depth and the billet feed at the constant high rotational speed of the mill does not significantly affect the range spread of the roughness values of the machined surface of the billet. However, the maximal errors were determined on the surface machined with the carbide mill after performing of the second test $(t$ $=3 \mathrm{~mm}, n=2000 \mathrm{rpm}, s=300 \mathrm{~m} / \mathrm{min}$ ). The roughness value of the machined surface of the billet decreases by $25 \%$ at $t=3 \mathrm{~mm}$. This recommendation is valid for the minimal and maximal values of the rotational speed of the high-speed mill and the billet feed.

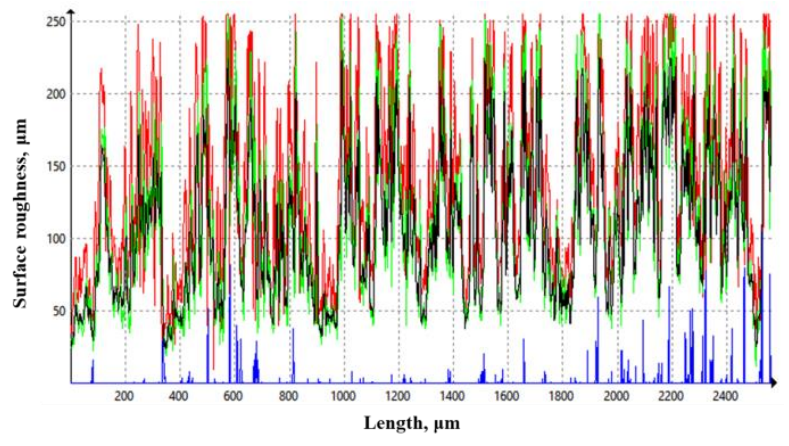

B

Figure 1 - The graphical presentation of the surface roughness after performing of the first test: $A$ - the end mill made of high-speed steel; $B$ - the end mill made of cemented carbide.

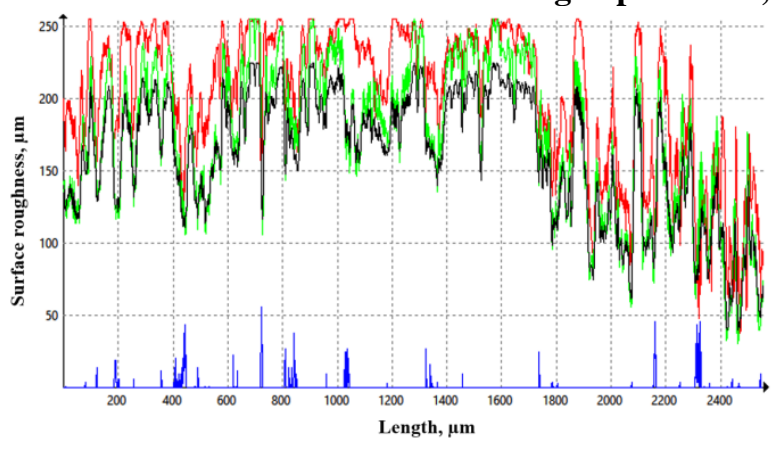

$\boldsymbol{A}$

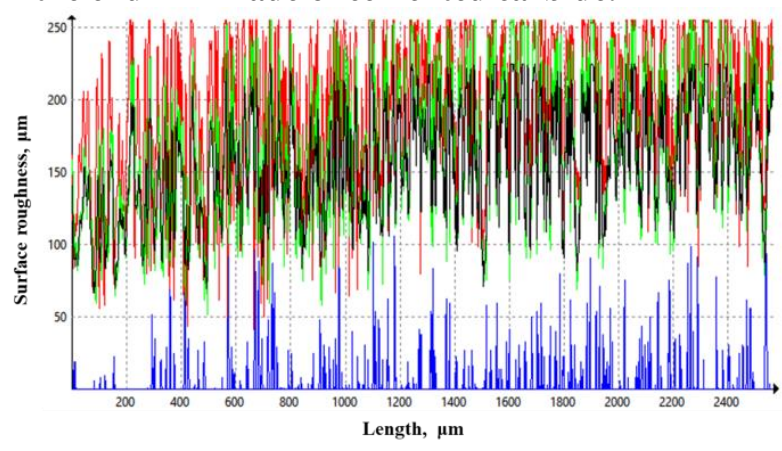

B

Figure 2 - The graphical presentation of the surface roughness after performing of the second test: $A$ - the end mill made of high-speed steel; $B$ - the end mill made of cemented carbide. 


\begin{tabular}{|c|c|c|c|c|c|c|}
\hline \multirow{4}{*}{ Impact Factor: } & ISRA (India) & $=3.117$ & SIS (USA) & $=0.912$ & ICV (Poland) & $=6.630$ \\
\hline & ISI (Dubai, UAI & $=0.829$ & РИНЦ (Russia & $=0.156$ & PIF (India) & $=1.940$ \\
\hline & GIF (Australia) & $=0.564$ & ESJI (KZ) & $=8.716$ & IBI (India) & $=4.260$ \\
\hline & JIF & $=1.500$ & SJIF (Morocce & $=5.667$ & OAJI (USA) & $=0.350$ \\
\hline
\end{tabular}

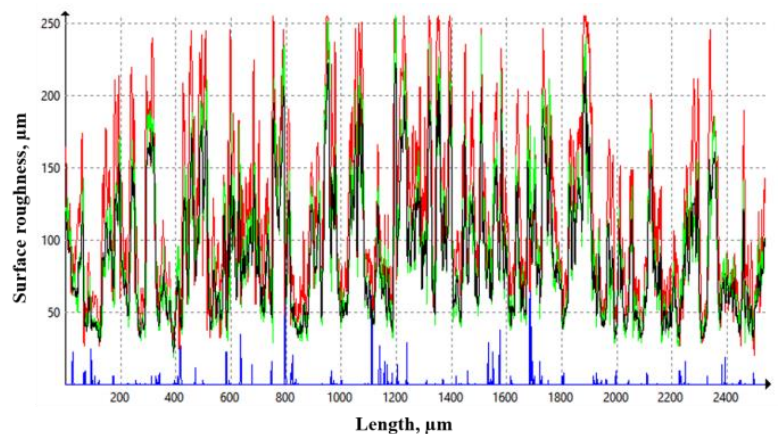

$A$

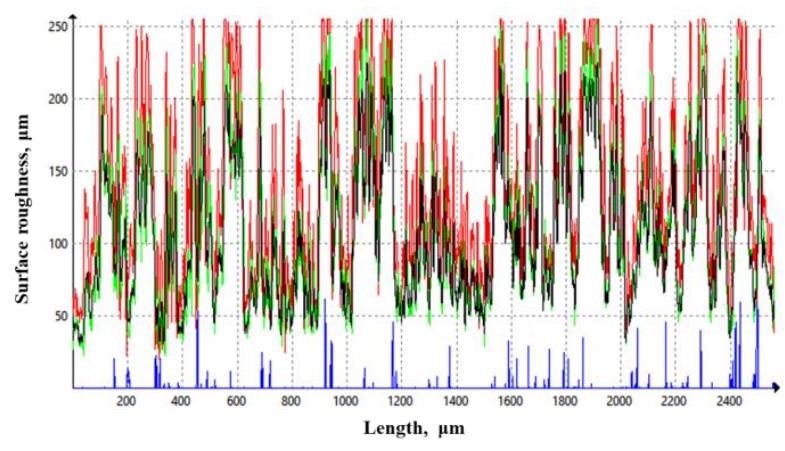

$\boldsymbol{B}$

Figure 3 - The graphical presentation of the surface roughness after performing of the third test: $A$ - the end mill made of high-speed steel; $B$ - the end mill made of cemented carbide.

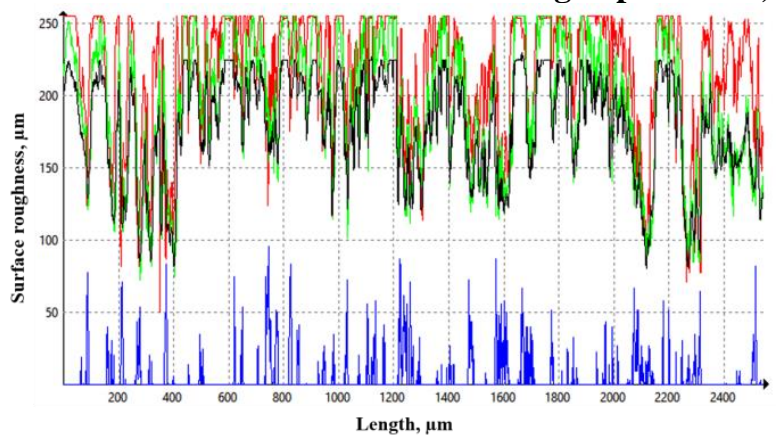

$\boldsymbol{A}$

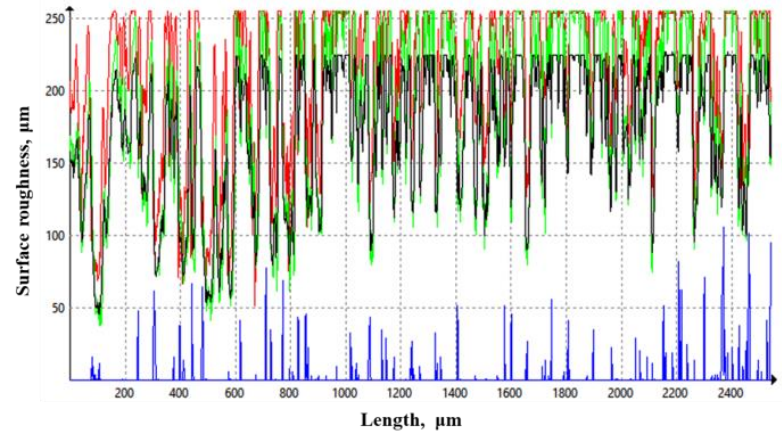

$B$

Figure 4 - The graphical presentation of the surface roughness after performing of the fourth test: $A$ - the end mill made of high-speed steel; $B$ - the end mill made of cemented carbide.

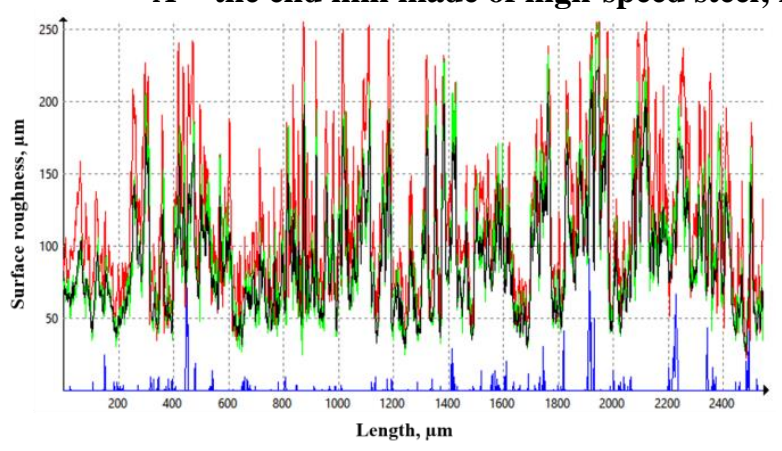

A

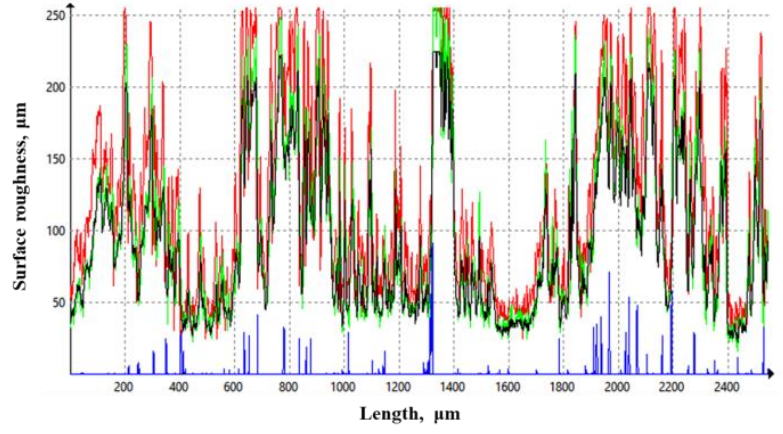

$B$

Figure 5 - The graphical presentation of the surface roughness after performing of the fifth test: $A$ - the end mill made of high-speed steel; $B$ - the end mill made of cemented carbide.

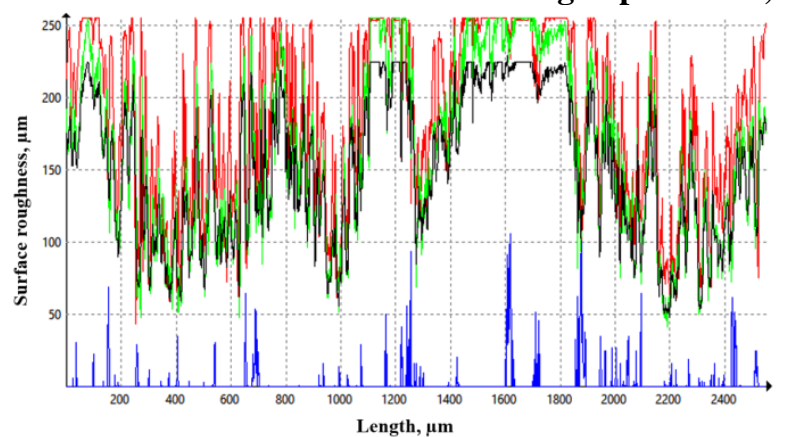

$\boldsymbol{A}$

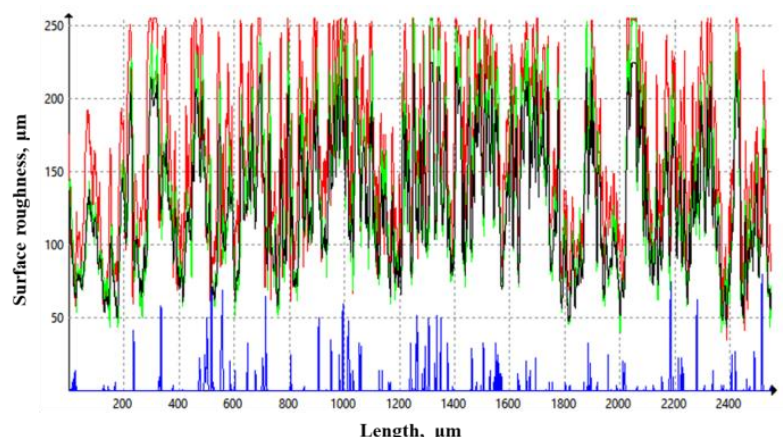

$B$

Figure 6 - The graphical presentation of the surface roughness after performing of the sixth test: $A$ - the end mill made of high-speed steel; $B$ - the end mill made of cemented carbide. 


\begin{tabular}{|c|c|c|c|c|c|c|}
\hline \multirow{4}{*}{ Impact Factor: } & ISRA (India) & $=3.117$ & SIS (USA) & $=0.912$ & ICV (Poland) & $=6.630$ \\
\hline & ISI (Dubai, UAI & $=0.829$ & РИНЦ (Russia & $=0.156$ & PIF (India) & $=1.940$ \\
\hline & GIF (Australia) & $=0.564$ & ESJI (KZ) & $=8.716$ & IBI (India) & $=4.260$ \\
\hline & JIF & $=1.500$ & SJIF (Morocce & $=5.667$ & OAJI (USA) & $=0.350$ \\
\hline
\end{tabular}

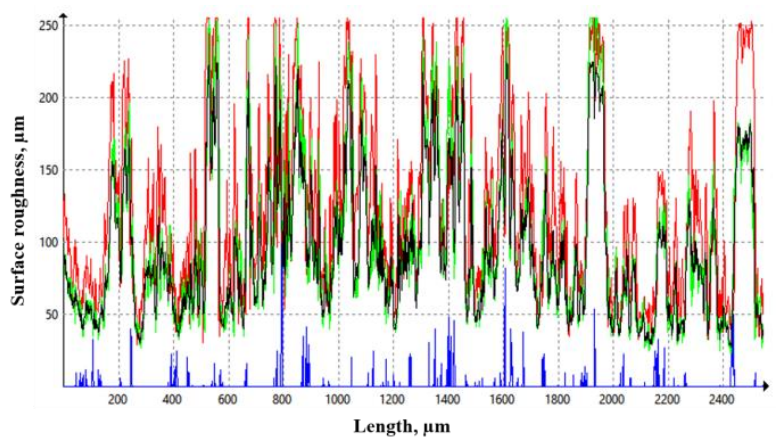

$\boldsymbol{A}$

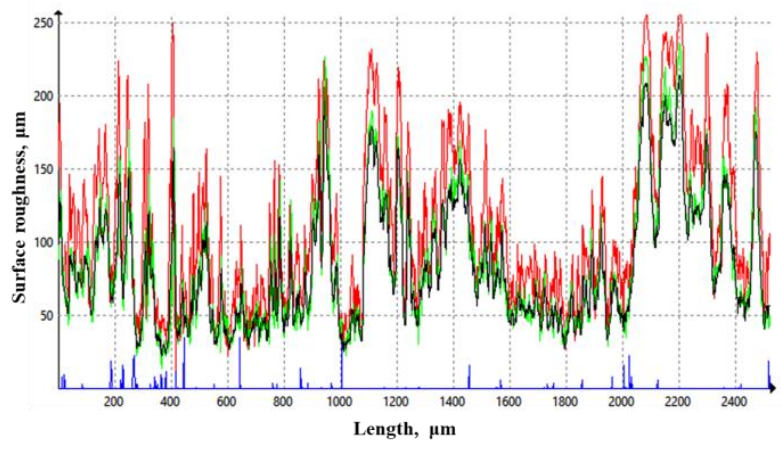

$B$

Figure 7 - The graphical presentation of the surface roughness after performing of the seventh test: $A$ - the end mill made of high-speed steel; $B$ - the end mill made of cemented carbide.

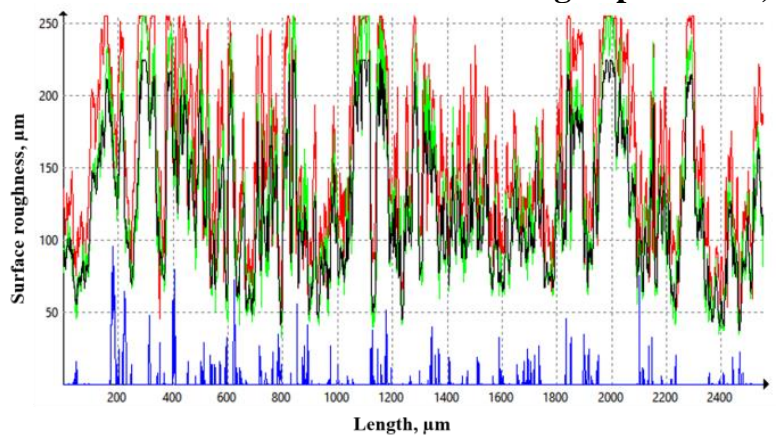

A

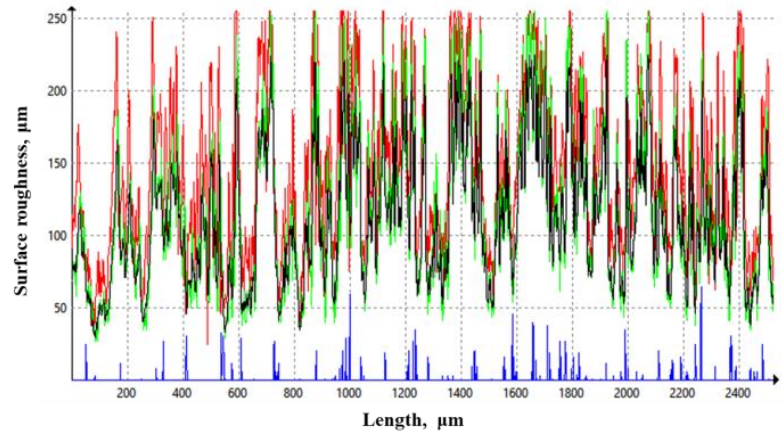

$B$

Figure 8 - The graphical presentation of the surface roughness after performing of the eighth test: $A$ - the end mill made of high-speed steel; $B$ - the end mill made of cemented carbide.

Thus, for the minimal error of the profile and decreasing of roughness of the machined surface of the aluminium billet is recommended to use the following most optimal milling modes: $t=3 \mathrm{~mm}, n=$ $10000 \mathrm{rpm}, s=300 \mathrm{~m} / \mathrm{min}$.

\section{Conclusion}

On the basis of the obtained images of roughness of the machined surfaces of the aluminium billet by milling, the following conclusions can be drawn:

1. The maximal value of the cutting depth, adopted when performing of the multifactor experiment, leads to less destabilization of the cutting process, and hence to less the profile errors of the machined surface of the billet than the minimal cutting depth.

2. Increasing of the rotational speed of the end mill (10000 rpm or more) leads to decreasing of the roughness value of the machined surfaces of the billet.

3. The billet feed should be taken at the lower level of the experiment, because when rough milling with the large cutting depths there are significant cutting forces.

\section{References:}

1. Lukianenko, O. (2014). The visualization of microroughness formation of machined surface on milling thin-walled workpiece. Scientific Journal "New materials and technologies in metallurgy and mechanical engineering", №2, 52-60.

2. Peigne, G. (2003). A model of milled surface generation for time domain simulation of highspeed cutting. Proceedings of the Institution of Mechanical Engineers, Part B: Journal of
Engineering Manufacture, Vol. 217, № 7, 919930.

3. Dujun, T. A., Pchelkin, V. M., \& Saharov, D. V. (2016). Study of resistance and surface roughness at milling alloy steel. Bulletin of modern technologies, 4(4), 47-51.

4. Kim, V. A., Schelkunov, Y. B., \& Breev, S. V. (2010). Roughness of machined surface during slab milling. Scholarly Notes of Komsomolsk- 


\begin{tabular}{llllll} 
& ISRA (India) $=\mathbf{3 . 1 1 7}$ & SIS (USA) $=\mathbf{0 . 9 1 2}$ & ICV (Poland) & $\mathbf{= 6 . 6 3 0}$ \\
Impact Factor: & ISI (Dubai, UAE) $=\mathbf{0 . 8 2 9}$ & PUHL (Russia) $=\mathbf{0 . 1 5 6}$ & PIF (India) & $=\mathbf{1 . 9 4 0}$ \\
& GIF (Australia) $=\mathbf{0 . 5 6 4}$ & ESJI (KZ) $=\mathbf{8 . 7 1 6}$ & IBI (India) & $\mathbf{4 . 2 6 0}$ \\
& JIF & $\mathbf{1 . 5 0 0}$ & SJIF (Morocco) $=\mathbf{5 . 6 6 7}$ & OAJI (USA) & $\mathbf{0 . 3 5 0}$ \\
\hline
\end{tabular}

na-Amure State Technical University, Issue I 1(1), 62-66.

5. Shulepov, A. V., \& Pyae Sone Win (2019). Tool engineering, metrology and informationmeasuring instruments and systems. Peerreviewed Journal Vestnik MSTU «STANKIN», 1(48).

6. Kozlov, S. V. (2018). Improving of the quality of milled surface of titanium parts. Innovations in science, № 9(85), 32-36.

7. Wang, S. Y., et al. (2006). A Surface Roughness Prediction Model for High Speed Milling. Manufacturing Technology and Machine Tools, 8.

8. Beruvides, G., Castaño, F., Quiza, R., \& Haber, R. E. (2016). Surface roughness modeling and optimization of tungsten-copper alloys in micromilling processes. Measurement: Journal of the International Measurement Confederation, vol. 86, 246-252.

9. Moola, M. R., Gorin, A., \& Hossein, K. A. (2012). Optimization of various cutting parameters on the surface roughness of the machinable glass ceramic with two flute square end mills of micro grain solid carbide. International Journal of Precision Engineering and Manufacturing, 13(9), 1549-1554.

10. Felhő, C., \& Kundrák, J. (2018). Effects of Setting Errors (Insert Run-Outs) on Surface Roughness in Face Milling When Using Circular Inserts. Machines, 6, 14. 